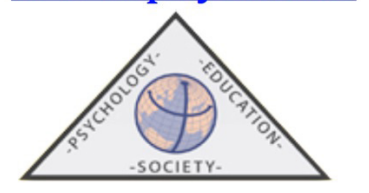

ISSN 2171-2085 (print) / ISSN 1989-709X (online)

Doi 10.25115/psye.v10i1.2658

\title{
Social Support by Teacher and Motivational Profile of Higher Education Students
}

\author{
Juan Antonio MORENO-MURCIA ${ }^{1}$ y Miguel CORBÍ ${ }^{2}$ \\ ${ }^{1}$ Universidad Miguel Hernández de Elche \\ ${ }^{2}$ Universidad de Burgos
}

(Received July 30, 2019, Accepted November 26, 2020)

\begin{abstract}
Currently, educational trends show how cognitive and affective-motivational integration are presented as key factors in the students' learning process. Therefore, the social support that students receive from teachers can play an important role in motivation towards learning, developing intrinsic motivations which favor their commitment. This study presents the validation of a measuring instrument into Spanish context about how the university students perceive the teacher social support and how it relates to motivational profiles. The sample had 396 university students (305 men and 91 women), 22.87 years average age, to whom social support and academic motivation were measured. After the analyses, The Interpersonal Behavior Scale showed adequate psychometric measures. Three motivational profiles were found. The data showed that students with a high self-determined profile present higher values in social support than those with a less self-determined profile. It is expected these results support the evidence to train motivating teachers related to a positive impact on the students' learning process.
\end{abstract}

Keywords: self-determination, autonomy support, cluster, university students, motivational profile.

\section{Apoyo social del docente y perfil motivacional en educación superior}

RESUMEN: La integración cognitiva y afectivo-motivacional se presentan como factores clave en el proceso de aprendizaje de los estudiantes. El apoyo social que reciben los estudiantes por parte de los docentes puede resultar importante en la motivación intrínseca hacia el aprendizaje del estudiante, favoreciendo su compromiso. Este trabajo presenta la validación de un instrumento al español sobre apoyo social por parte del docente percibido por el estudiante, y su relación con los perfiles motivacionales. Se midió el apoyo social docente y su motivación académica a 396 estudiantes universitarios. El inventario The Interpersonal Behavior Scale mostró adecuadas medidas psicométricas. Se obtuvieron tres perfiles motivacionales, donde un perfil más autodeterminado presentaba mayores valores en el apoyo social que uno menos autodeterminado.

Palabras clave: auto-determinación, apoyo a la autonomía, clúster, universidad, perfil motivacional Correspondencia: Miguel Corbí. Calle Don Juan de Austria, s/n, 09001 Burgos. E-mail: mcorbi@ubu.es 


\section{Introduction}

Educational process is built from the interaction and communication among teachers, students and didactic materials (Zaikin et al., 2016). Currently, the main trends about formation consider that in several levels as cognitive and affective-motivational, where the second one even stands over the first one (Bolenz, Reiter, \& Eppinger, 2017; García \& Doménech, 2002; Quin, Hemphill, $\&$ Heerde, 2017). Those authors assess intentions, perceptions, own beliefs and goals that students may contemplate. Motivation toward experience is an essential factor for the students' self-regulated learning (Brophy, 2010; Schunk, Pintrich \& Meece, 2008). That is why, chasing the motivation in the classroom, there are lots of researches about the students implication and its relation between student and teacher, learning trends and university teachers assessment, and students perception about good teacher features (De Vincenzi, 2009; Gargallo, Sánchez, Ros, \& Ferreras, 2010; Pintrich \& De Groot, 1990).

Teacher and student relationship is not just determined by needs satisfaction of the student, but emotional level is present too in order to achieve the student success (Sulkowski \& Simmons, 2018). This positive relation is mainly determined by teacher propinquity, open communication and social support (Drugli, 2013), although assessing their knowledge and creating free expression environments is needed too (Silveira, 2018). When students perceive social support by teachers, emerge a reciprocate feeling that leads a higher implication and respect for the rules of the lecture (Chiu \& Chow, 2011; Longobardi, Prino, Marengo, \& Settanni, 2016). By contrary, when students perceive some unfair discipline and low teacher support, tent to show less esteem and cooperation in their studies (Lei, Cui, \& Chiu, 2018). That is why it seems necessary further knowledge about teacher social support perceived by students.

Regarding Self-Determination Theory or SDT (Ryan \& Deci, 2000; 2013) motivation is interpreted as a continuum between two extremes, great and low determined regulation, with intermediate stages. From the most to the least we must differ: intrinsic motivation, identified regulation, introjected regulation, external regulation and demotivation. In this sense, self-determined motivation has a positive influence in acquisition and interpretation of information processes, even predicting the academic success (Kriegbaum, Jansen, \& Spinath, 2015; Orsini, Binnie, \& Wilson, 2016). Currently, this theory based in a cognitive evaluation theory (CET; Deci, 1985) can be interpreted by a new paradigm that differs between autonomous motivation and controlled motivation. This way, autonomous motivation is related with the regulation of behavior through experiences of volition, psychological freedom, and reflective selfendorsement as well as identified regulation and integrated regulation, both IM. In contrast, controlled motivation refers to the regulation of behavior with the experiences of pressure and coercion to think, feel, or behave in particular ways. In this case, both external regulation and introjected regulation are controlled forms of motivation (Ryan \& Deci, 2019; Vansteenkiste, Niemiec, \& Soenens, 2010). Anyway, back to the interpretation from the cognitive evaluation theory (CET), to achieve the self-determined motivation is needed to satisfy three basic psychological needs (BPN) in a social context, described by Vallerand and Lalande (2011), as task autonomy, student perceived competence, and relatedness. All of them take part to reach an integrated social development and personal wellness, although autonomy and competence are emphasized (Cook \& Artino, 2016). 
The concept of social support has been polysemic and heterogeneous, although it was progressively concreted (Vaz, 2010), due to different models as work support, received support, perceived support, and the definitions of numerous tools of each model (Carvalho, Pinto, Pimentel, Maia, \& Mota-Pereira, 2011; Siqueira, 2008). Family, peers and teachers shape a microsystem, in the educative environment, where student social support is hosted (Bronfenbrenner, 1986; Pössel et al., 2018), and where received support by teachers interferes positively in social and intellectual competences (Fredriksen \& Rhodes, 2004). Numerous studies have identified a positive relation between teacher social support and the improvement of self-steem and general wellness, a reduction of depression symthomps, and academic achievements (Bradshaw, Waasdorp, \& Leaf, 2012; Davis, 2003; Durlak, Weissbert, Dymnicki, Taylor, \& Schellinger, 2011; Pössel, Rudasill, Sawyer, Spence, \& Bjerg, 2013). Regarding the opinion of Lam, Wong, Yang, and Liu (2012), the benefits related to academic success are based on the relationship between perceived social support and the higher student implication in their duties, altough the origen of the social support may be proceed from the teacher as well as family or partners (Perdue, Manzeske, \& Estell, 2009). On their side, a research of Chu, Saucier, and Hafner (2010) observed a higher significant relation between teacher social support and student general wellness than related to family and partners.

Regarding social support measure tools, the research community has adapted to several specific fields, where health stands out. On this field, we highlight Silverman (2014) who used The Multidimensional Scale of Perceived Social Support (MSPSS) with a sample of psychiatric patients; Elmose and Lasgaard (2017), who used the Danish version of the scale Social Support Scale for Children (SSSC) by Harter (1985) with a sample of children with ADHS; and Rzeszutek (2017), who used the Polish version of the scale Berlin Social Support Scales (BSSS) with HIV patients. On the education field, the most frequent scales that include teachers social support are the Survey of Children's Social Support (SOCSS) by Dubow and Ullman (1989), and Child and Adolescent Social Support Scale (CASSS) by Malecki, Demaray, and Elliott (2000), which include 5 and 12 items, respectively, related to teacher social support. Recently, we highlight the research of Loera, Martini, Viotti, and Converso (2016), who used the perceived social support scale User-Initiated Support Scale (UISS) with a sample of kindergarten teachers. On the other hand, from a qualitative point of view, Reeve, Shumaker, Yearwood, Crowell, and Riley (2013), used four questions about how the education students feel in different situations. Among the versions validated into Spanish, stands out The Perceived Autonomy Support Scale for Exercise Settings (PASSES) by Hagger et al. (2007) and validated into Spanish by Moreno, Parra, and González-Cutre (2008). Regarding more used scales about BPN in education, we can highlight the Basic Needs Satisfaction in General Scale (BNSG-S), by Gagné (2003), validated into Spanish by González-Cutre et al. (2015), which is composed of 21 items. Currently, the scientists keep developing scales about the specific or general interpersonal behavior for specific collectives. Among the most recent, we highlight The Interpersonal Behavior Scale (IBS) by Pelletier, Beaudry, Sharp, and Otis (2008), which includes 12 items for three BPN and pretends be validated into Spanish in the present paper; the Continuous Assessment of Interpersonal Dynamics (CAID), by Sadler, Ethier, Gunn, Duong, and Woody (2009), which evaluates two dimensions as affiliation and hierarchy; the Cuestionario de Apoyo a las Necesidades Psicológicas Básicas (CANPB), by Sánchez-Oliva, Leo, Amado, Cuevas, and García-Calvo (2013), which supposes 
a tool to measure basic psychological needs on the on the field of Physical Education; and the Interpersonal Dynamics in Injecting Partnerships (IDIP), by Morris et al. (2017), that assess the interpersonal relationships in drug-dependent population. Finally, we highlight the general scale Balance Measure of Psychological Needs (BMPN), by Sheldon and Hilpert (2012), to be used in the educational field, Basic Needs Satisfaction at College Scale, by Jenkins-Guarnieri, Vaughan, and Wright (2015), that is the result of a modification of the BNSW-S.

On the education field, motivation toward learning process is considered as an internal essential resource from the point of view of self-regulated learning, whereby numerous authors have researched about the response of the students to different learning difficulties (Engelschalk, Steuer, $\&$ Dresel, 2016). Whitin this process, the teacher social support perceived by students, is considered as a determinant factor in the creation of a positive learning environment that favors the teacher labor to enhance the students' motivation. (Drugli, 2013; Sulkowski, \& Simmons, 2018). That is why numerous researches about motivation toward the learning process, head to the student-teacher relationship. At this way, the objective of this paper has been the validation of The Interpersonal Behavior Scale (IBS) into Spanish context and show its relationship with the motivational profile. It is expected that the students who perceive more teacher social support manifest a higher self-determined motivational profile.

\section{Methods}

\section{Participants}

The sample was composed of 396 students (305 men and 91 women) from 6 Spanish universities, aged $22.87(S D=3.10)$, that were studding 3th and 4th grades of Physical Activity and Sports.

\section{Measures}

Social support. The Interpersonal Behavior Scale (IBS) by Pelletier et al. (2008), composed of 12 items, was used to evaluate the teacher social support, where three constructs were measure: autonomy support (e.g. " “...give me a lot of opportunities to make my own decisions about what I do"), competence support (e.g. “...transmit me I am able to learn”), and relatedness support (e.g. "...enjoy spending time with me"). The previous sentence is "My teachers, almost ever...". A Likert scale from 1 (never) to 5 (always) was used.

Academic motivation. To measure the students' academic motivation, we use the Échelle de Motivation en Éducation (EME) (Vallerand, Blais, Brière, and Pelletier, 1989), translated and validated into Spanish by Núñez, Martín-Albo, and Navarro (2005). The instrument is composed of 28 items, preceded by the sentence "Why do you study?" and distributed in seven sub-scales with four items: demotivation (e.g. "I do not know why I go to the school and I do not care neither"), external regulation (e.g. "To get a better salary in the future"), introjected regulation (e.g. "I feel important when I do the task well in class"), identified regulation (e.g. "Because it will help me to pick a better decision about my professional orientation"), intrinsic motivation 
to know (e.g. "Because my studies let me keep learning a lot of interesting things"), intrinsic motivation towards accomplishments (e.g. "Because of the satisfaction I feel when I overcome difficult academic activities") and intrinsic motivation to experience stimulation (e.g. "Because I really like to assist to class"). Responds were scored with a seven-points Likert scale, from 1 (It does not correspond at all) to 7 (It does totally correspond). The Cronbach's alpha values were .82 to intrinsic motivation (IM) to know, .69 towards accomplishments IM, .82 to experience stimulation IM, .75 to identified extrinsic motivation (EM), .70 to introjected EM, .70 to external regulation EM, and .86 to demotivation.

\section{Procedure}

The back-translation strategy was the first step to adapt the instrument from English into Spanish (Hambleton \& Patsula, 1998). After the translation into Spanish, a group of translators did it again to English in order to search the coincidences with the original version. Then, the items were evaluated by three experts (Lynn, 1986), estimating all of them the pertinence to measure the construct for which were created, besides the correct drafting of them. After that, the instrument was filled up by a small group of students to verify the proper comprehension and, if not, shift what needed. Prior to data gathering, the responsible person of each college was informed about the objectives and asked for collaboration. The questionnaires were administered in presence of the principal researcher. The anonymity of the volunteers and the sincerity while answering were noticed. The time needed to complete the instrument was 10 minutes approximately.

\section{Data analysis}

Preliminary analysis. The descriptive statistics of all the items of the questionnaire were calculated (mean scores and standard deviations), internal consistency of every factor was analyzed with Cronbach's alpha coefficient and bivariated correlations of all the variables. To test the construct reliability, a confirmatory factorial analysis was examined, besides the temporal stability. The construct validity was tested by a confirmatory analysis to corroborate the number and distribution of the factors of the scale in Spanish.

Main analysis. A cluster analysis identifies homogeneous groups, based on the shared characteristics they possess (Härdle \& Simar, 2003). Therefore, the groupings obtained allow the researcher to examine differences between profiles rather than looking at interindividual differences. In addition, a multivariate variance analysis (MANOVA) was used in order to relate social support with the motivational profiles. Data were analyzed with SPSS 21.0 and AMOS 21.0.

\section{Results}

\section{Preliminary results}

Confirmatory factorial analysis of Social Support scale. A test carried out in order to evaluate the normality of the distribution of the variables revealed that none of them was normally distributed 
(multivariate skewness and kurtosis tests). The Confirmatory factorial analysis (CFA) was made based on 12 measures and three latent constructs. The reliability of the measure model was considered through a set of fit coefficients recommended by several authors (Bentler, 1990; Bollen \& Long, 1993; McDonald \& Marsh, 1990), also known as goodness-of-fit indexes to evaluate the measure models with empirical data: $\chi 2, \chi 2 /$ d.f., RMSEA (Root Mean Square Error of Approximation), RMSR (Root Mean Square Residual) and incremental indexes (CFI, IFI and TLI). Those goodnessof-fit indexes are suitable when $\chi 2 /$ d.f. is lower than 5, incremental indexes (CFI, IFI and TLI) are higher than .90 and mistake indexes (RMSEA and RMSR) are lower than .08 (Browne \& Cudeck, 1993; Hu \& Bentler, 1999). The maximum-likehood estimation method was used with bootstrapping procedure, since the result of Mardia multivariate coefficient was 25,35, what indicates lack of multivariate normality being beneath the reference value of 70 (Rodríguez \& Ruiz, 2008). That is also the reason why, following to Finney and DiStefano (2006), the robust maximum-likehood estimation method (Byrne, 2001) was used. After the initial analysis, data showed low standardized regression weight in items 2 (relatedness support) and 9 (competence support), with values of .150 and -.209 respectively, so it was made a new analysis erasing both items, obtaining at this way values higher than .30 in all the items (Table 1). The indexes obtained were suitable: $\chi 2(51, \mathrm{~N}=396)=$ $174.68 ; p=.001 ; \chi 2 /$ d.f. $=3.42 ; \mathrm{IFI}=.92 ; \mathrm{TLI}=.90 ; \mathrm{CFI}=.92 ; \mathrm{RSMR}=.05 ; \mathrm{RMSEA}=.07$.

Table 1. Estimated parameters of AFC to the social support scale.

\begin{tabular}{|c|c|c|c|c|c|c|}
\hline & $\mathbf{M}$ & SD & Asymmetry & Kurtosis & SRW & QM \\
\hline 1. Is sincerely concern about me & 2.92 & 0.85 & -0.02 & 0.318 & 0.69 & -0.17 \\
\hline $\begin{array}{l}\text { 3. When I ask for help to sort a problem, I am } \\
\text { incited to think before giving me an opinion }\end{array}$ & 3.26 & 0.95 & -0.38 & 0.004 & 0.41 & -3.08 \\
\hline $\begin{array}{l}\text { 4. Makes me feel self-confident in my learning } \\
\text { capacity }\end{array}$ & 3.3 & 0.89 & -0.27 & 0.1 & 0.77 & -2.22 \\
\hline 5. Encourages me to be myself & 3.24 & 1.03 & -0.26 & -0.39 & 0.76 & -2.08 \\
\hline 6. Enjoys spending time with me & 2.68 & 0.96 & 0.05 & -0.33 & 0.63 & 0.421 \\
\hline $\begin{array}{l}\text { 7. The information I received is useful for my } \\
\text { learning }\end{array}$ & 3.69 & 0.92 & -0.65 & 0.4 & 0.66 & -5.28 \\
\hline 8. Seems to be really interested on what I do & 3.07 & 0.95 & -0.11 & -0.36 & 0.8 & -0.92 \\
\hline $\begin{array}{l}\text { 10. Gives me opportunities to make my own } \\
\text { decisions in what I do }\end{array}$ & 3.19 & 0.9 & -0.08 & -0.28 & 0.67 & -0.64 \\
\hline 11. Transmits me I am able to learn & 3.49 & 0.91 & -0.4 & 0.03 & 0.75 & -3.27 \\
\hline $\begin{array}{l}\text { 12. Recognizes my thoughts and feelings } \\
\text { although they may be contraries to theirs }\end{array}$ & 3.08 & 0.99 & -0.17 & -0.29 & 0.69 & -1.36 \\
\hline
\end{tabular}

Note: SRW $=$ Standardized Regression Weight; QA = Quadratic Mean.

Internal consistency and temporal stability. The internal consistency of the scale factors was calculated with Cronbach's alpha coefficient, reaching an Alpha value of .73 to autonomy social support, .76 to competence social support; and .74 to relatedness social support. To analyze temporal stability of scale, we counted on a 28-students sample, aged from 23 to 34 years ( Avg = 
25.63; $S D=3.62)$. They fill up the scale twice in a three-weeks space of time. The intraclass correlation coefficient (ICC) was calculated for both moments (pre-posttest). The mean value was $3.31(S D=.67)$ and $3.07(S D=.77)$ with an ICC value of .89 for autonomy; $3.65(S D=.63)$ and $3.33(S D=.69)$ with an ICC value of .91 to competence; and $3.01(S D=.61)$ and $2.84(S D=.72)$ with an ICC value of .93 to relatedness. ICC values within .70 and .80 indicate suitable stability; within .80 and .89, moderate; and .90 or upper, high stability (Vincent, 1995).

\section{Main results}

Descriptive and correlation analysis. Results showed higher values in competence social support, followed by autonomy and relatedness. Regarding types of academic motivation, higher values were attributed to identified external motivation, followed by intrinsic motivation to know. Behind this, it is followed by intrinsic motivation to experience stimulation, introjected, extrinsic and demotivation. Excepting the dimension of external extrinsic motivation and demotivation, correlated analysis (Table 2) showed a positive and significant relationship between teacher perceived social support and the rest of student's motivations. Demotivation showed a positive relationship with external extrinsic and introjected motivation. In contrast, that showed a negative and significant relationship with the intrinsic motivation to know and identified extrinsic motivation. Thus, demotivation showed a negative relationship with autonomy support either.

Table 2. Descriptive and correlations among variables of the research

\begin{tabular}{lccccccccccccc}
\hline & M & SD & $\mathbf{\alpha}$ & $\mathbf{1}$ & $\mathbf{2}$ & $\mathbf{3}$ & $\mathbf{4}$ & $\mathbf{5}$ & $\mathbf{6}$ & $\mathbf{7}$ & $\mathbf{8}$ & $\mathbf{9}$ & $\mathbf{1 0}$ \\
\hline 1. S. autonomy & 3.19 & .72 & .73 & - & $.74^{* *}$ & $.75^{* *}$ & $.20^{* *}$ & $.21^{* *}$ & $.27^{* *}$ & $.20^{* *}$ & $.15^{* *}$ & .05 & -.07 \\
2. S. competence & 3.49 & .75 & .76 & - & - & $.63^{* *}$ & $.32^{* *}$ & $.26^{* *}$ & $.33^{* *}$ & $.31^{* *}$ & $.18^{* *}$ & -.04 & $-.25^{* *}$ \\
3. S. relatedness & 2.89 & .75 & .74 & - & - & - & $.17^{* *}$ & $.24^{* *}$ & $.36^{* *}$ & $.16^{* *}$ & $.17^{* *}$ & .06 & .01 \\
4. IM to know & 5.51 & .98 & .82 & - & - & - & - & $.68^{* *}$ & $.59^{* *}$ & $.65^{* *}$ & $.42^{* *}$ & $.15^{* *}$ & $-.27^{* *}$ \\
5. IM accomplishment & 5.01 & 1.16 & .82 & - & - & - & - & - & $.63^{* *}$ & $.45^{* *}$ & $.64^{* *}$ & $.28^{* *}$ & -.06 \\
6. IM experience & 4.47 & 1.22 & .69 & - & - & - & - & - & - & $.51^{* *}$ & $.54^{* *}$ & $.25^{* *}$ & -.02 \\
7. EM identified & 5.69 & .96 & .75 & - & - & - & - & - & - & - & $.37^{* *}$ & $.21^{* *}$ & $-.39^{* *}$ \\
8. EM introjected & 4.57 & 1.38 & .70 & - & - & - & - & - & - & - & - & $.50^{* *}$ & $.17^{* *}$ \\
9. EM external & 4.24 & 1.09 & .70 & - & - & - & - & - & - & - & - & - & $.45^{* *}$ \\
10. Demotivation & 2.43 & 1.56 & .86 & - & - & - & - & - & - & - & - & - & - \\
\hline
\end{tabular}

Note: $* * \mathrm{p}<.001 ; \mathrm{S}=$ Support; $\mathrm{IM}=$ Intrinsic motivation; $\mathrm{EM}=$ Extrinsic motivation.

Cluster analysis. Due to cluster analysis is sensitive to outliers, all cases more than three standard deviations from the mean were removed (Liu, Wang, Tan, Koh, \& Ee, 2009). To determine motivational groups, we made a hierarchical cluster analysis using Ward method, considering a 
distance of 10 points to identify optimal groups. The resulted dendogram suggested three motivational profiles (Table 3), whose adequacy was evaluate based on the increased agglomeration coefficient. In accordance with Norusis (1992), the small coefficients indicate high homogeneity among cluster members, while higher coefficients show big differences among them. We got three different motivational profiles (Figure 1): self-determination not defined (cluster 1) with moderated scores both in demotivation and intrinsic and extrinsic motivation; medium self-determination profile (cluster 2), with moderated scores in intrinsic and extrinsic motivation, and lower scores in demotivation; and a high self-determination profile (cluster 3 ) which showed high scores in intrinsic and extrinsic motivation and lower scores in demotivation (Table 3).

Table 3. Mean score and standard deviations of the cluster variables.

\begin{tabular}{lcccccc}
\hline & \multicolumn{2}{c}{ Cluster 1 } & \multicolumn{2}{c}{ Cluster 2 } & \multicolumn{2}{c}{ Cluster 3 } \\
\cline { 2 - 7 } & \multicolumn{2}{c}{$(\mathbf{n}=\mathbf{1 2 6})$} & \multicolumn{2}{c}{$(\mathbf{n = 1 8 1 )}$} & \multicolumn{2}{c}{$(\mathbf{n = 8 9 )}$} \\
\cline { 2 - 8 } & $\mathrm{M}$ & $\mathrm{SD}$ & $\mathrm{M}$ & $\mathrm{SD}$ & $\mathrm{M}$ & $\mathrm{SD}$ \\
\hline IM to know & 5.16 & .91 & 5.31 & .93 & 6.41 & .53 \\
IM accomplishment & 4.99 & .95 & 4.48 & 1.09 & 6.12 & .65 \\
IM experience stimulation & 4.40 & 1.19 & 4.01 & 1.06 & 5.52 & .84 \\
EM identified & 5.16 & .83 & 5.66 & .95 & 6.47 & .52 \\
EM introjected & 4.98 & .97 & 3.59 & 1.09 & 5.96 & .79 \\
EM extrinsic & 4.89 & .83 & 3.57 & 1.02 & 4.68 & .69 \\
Demotivation & 4.39 & 1.06 & 1.53 & .66 & 1.49 & .61
\end{tabular}

Note: $\mathrm{IM}=$ Intrinsic motivation; $\mathrm{EM}=$ External motivation .

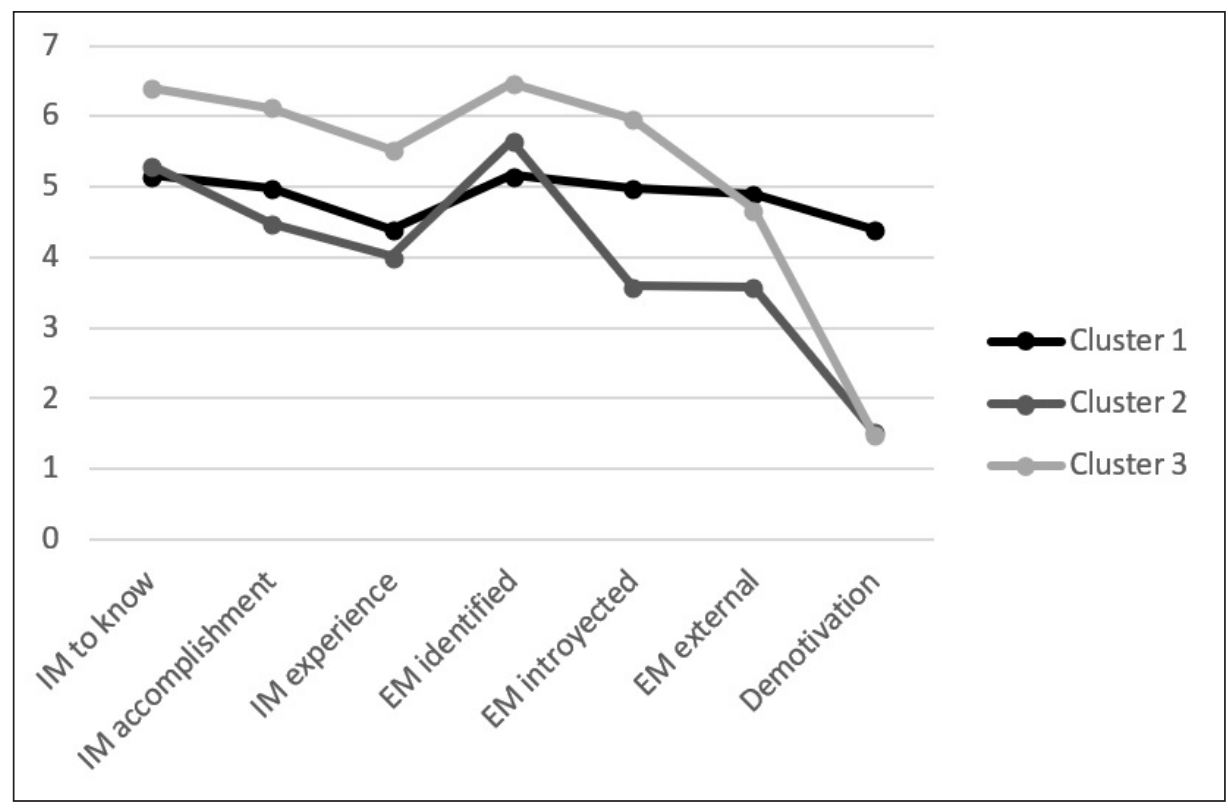

Figure 1. Hierarchical cluster analysis with Ward method. IM = Intrinsic Motivation; EM = Extrinsic Motivation; Cluster 1: Selfdetermination not defined group; Cluster 2: Medium self-determination profile group; Cluster 3: High self-determination profile group. 
Multivariate analysis. To examine the features of each motivational profile regarding social support, a differential analysis was made with clusters as independent variable and the three factors of social support as dependent variables. Differences was found (Wilk's lambda $=.87, \mathrm{~F}(3,427)$ $=8.77, \mathrm{p}<.001, \eta 2=.06$ ) among different clusters in all variables (Table 4), showing that the students with higher self-determination profile presented higher social support values than those with a lower self-determination profile (Bonferroni Post hoc test). The effect sizes are between .01 and $.137(d=20, d=0,80)$ so it can be considered as small and medium effect (Cohen, 1988).

Table 4. Multivariate analysis

\begin{tabular}{|c|c|c|c|c|c|c|c|c|c|}
\hline \multirow{3}{*}{ Variables } & \multirow{2}{*}{\multicolumn{2}{|c|}{$\begin{array}{l}\text { Cluster } 1 \\
(n=126)\end{array}$}} & \multirow{2}{*}{\multicolumn{2}{|c|}{$\begin{array}{l}\text { Cluster } 2 \\
(n=181)\end{array}$}} & \multirow{2}{*}{\multicolumn{2}{|c|}{$\begin{array}{c}\text { Cluster } 3 \\
(n=89)\end{array}$}} & \multirow{3}{*}{$\mathbf{F}$} & \multirow{3}{*}{$\eta^{2}$} & \multirow{3}{*}{ Post hoc } \\
\hline & & & & & & & & & \\
\hline & $M$ & $S D$ & $M$ & $S D$ & $M$ & $S D$ & & & \\
\hline 1. Autonomy social support & 3.16 & .76 & 3.10 & .64 & 3.41 & .75 & $5.50 *$ & .03 & $1-3 / 2-3$ \\
\hline 2. Competence social support & 3.28 & .77 & 3.47 & .68 & 3.84 & .72 & $16.11 * *$ & .08 & $1-2 / 1-3 / 2-3$ \\
\hline 3. Relatedness social support & 2.92 & .83 & 2.77 & .67 & 3.07 & .74 & $5.00 *$ & .03 & $2-3$ \\
\hline Wilk's $\Lambda$ & & & & & & & .87 & .06 & \\
\hline F multivariate & & & & & & & $8.77 * *$ & & \\
\hline
\end{tabular}

Note: $* \mathrm{p}<.05 ; * * \mathrm{p}<.01 ; M=$ Mean score; $S D=$ Standard deviation

\section{Discussion}

The aims of this research were validating the social support scale (The Interpersonal Behavior Scale) by Pelletier et al. (2008) into Spanish and relating this with the students' motivational profile, as it was done in other countries (Cuevas, García-Calvo, \& Contreras, 2013). Since the students who perceived higher teacher social support presented a higher self-determinate motivational profile, the initial hypothesis is confirmed.

The validity evidence based on internal structure and reliability of the scale validated into Spanish are shown by the psychometric results, corroborating the relative factors to autonomy, competence and relatedness supports. Due to the low regression weights, this first approach to the Spanish context showed that two items of the scale are not properly explained, and they were erased.

The cluster analysis exposed three motivational profiles based on the Self-Determination Theory (SDT) by Deci and Ryan (2002). The first one encompasses to whom got moderated scores in intrinsic and extrinsic motivation, as well as in demotivation. The second profile includes to whom showed moderated scores in both types of motivation, and lower scores in demotivation. The third profile was composed of who presented higher scores in intrinsic and extrinsic motivation, while kept lower scores in demotivation. The SDT suggests that two motivational profiles (self-determined and no self-determined) could be consider as opposite. However, as many re- 
searches show (Paixão and Gamboa, 2017; Ratelle, Guay, Vallerand, Larose, and Senécal, 2007), a not clearly defined group may merge, what supports the existence of intrinsic and extrinsic regulation forms coexisting in a real environment (Moran, Diefendorff, Kim, and Liu, 2012; Vansteenkiste, Sierens, Soenens, Luyckx, and Lens, 2009). In present research, the obtained cluster with no defined self-determination coincides with observed in other investigations with high school and college students (Boiché, Sarrazin, Grouzet, Pelletier, and Chanal, 2008; Paixão and Gamboa, 2017). Nevertheless, while the two others groups in those researches observes both a self-determined and a no-determined cluster, our results suggest two self-determined groups with different intensity, what has been shown in the reserches with a higher number of motivational profiles (Liu, Wang, Tan, Koh, and Ee, 2009; Moran et al., 2012; Vansteenkiste et al., 2009).

Our results have revealed a positive relationship between perceived social support by the teachers and the students' academic motivation. Thus, the influence of social factors on the students' self-determined motivation is proved as occurs in similar investigations (Cuevas et al., 2013; Zaikin et al., 2016). However, the profiles with an intrinsic motivation to know try to understand and analyze new contents regardless the cluster. That means that the more interest to acquire new knowledge, the more disposition to relate it with previous knowledge and to think further about it, according to the points made by Niemic and Ryan (2009).

Ryan and Deci (2000a), suggested that the students will be more intrinsic motivated as far as the teachers propose more interesting, challenged and new tasks, so it is very important to enhance the intrinsic motivation in order to obtain higher academic performance. Likewise, the way to show both the contents and the assessment results may stand for a big influence in the student's motivation. (Silveira, 2018; Zhuang, Feng, and Liao, 2017). It means, the student's motivation could be enhanced by little changes made by the teacher in the educative environment, as long as the special features were attended (Engelschalk et al., 2016; Orsini et al., 2016). According the opinion of other authors, the students with higher intrinsic motivation toward studies, dedicate more time and energy to the class tasks, so they acquire and process new information better (Longobardi et al., 2016; Niemic and Ryan, 2009).

The relationship between teacher social support and student's academic intrinsic motivation indicates that the teachers can promote the significant learning, connecting new knowledge with student's previous cognitive baggage (knowledge, experiences) in order to facilitate comprehension (León, Núñez, Ruiz-Alfonso, and Bordón, 2015). As suggested Koch, Dirsch-Weigand, Awolin, Pinkelman, and Hampe (2017), in college, project-based-learning improve the students' commitment with their own knowledge. However, we must remind that this kind of motivation is influenced by domestic environment, so a lot of student could obtain this predisposition toward knowledge out of academic environment (Riley, 2016). Anyway, as it is supported by Cheon et al. (2014), several studies based on correlation show the more teachers with autonomy support, the more satisfaction of psychological needs, autonomy motivation and higher wellness through learning, so students could improve their academic results according our research.

In interpreting the findings of these studies, some limitations must be considered. Integrated regulation was not considered in this study, despite the fact it is been integrated in other scales in Spanish language. On the other hand, this study is a correlational work without an intervention 
which facilitates the control of several covariables. Also, the sample size is enough but not large. Likewise, the validation protocol of the social support scale forced to erase two items from the original scale, although we must remind this has just a latent construct. Moreover, the motivational profiles described by the cluster do not establish remarkable differences between them. Futures studies must design procedures based on interventions to inquire about influence factors of both intrinsic and extrinsic motivation of the students. Also, it must include several data collection throughout the process in order to enhance empiric power.

In conclusion, this work has validated the social support scale into Spanish with suitable psychometric measures and has demonstrated the relationship between teacher social support and self-determined motivational profiles of students. Nevertheless, exists a vast field of investigation where it seems appropriate to define needs and measures in educative environments in order to keep forming teachers who provide an adequate autonomy support to students for keeping their motivation throughout their academic stage.

\section{References}

Bentler, P. M.(1990). Comparative fit indexes in structural models. Psychological bulletin, 107(2), 238. doi:10.1037/0033-2909.107.2.238

Bentler, P. M. (1990). Comparative fit indexes in structural models. Psychological bulletin, 107(2), 238. doi:10.1037/0033-2909.107.2.238

Boiché, J. C., Sarrazin, P. G., Grouzet, F. M., Pelletier, L. G., \& Chanal, J. P. (2008). Students' motivational profiles and achievement outcomes in Physical Education: A self-determination perspective. Journal of Educational Psychology, 100(3), 688-701. doi:10.1037/00220663.100.3.688

Bolenz, F., Reiter, A. M., \& Eppinger, B. (2017). Developmental changes in learning: Computacional mechanisms and social influences. Frontiers in Psychology, 8, 2048. doi:10.3389/fpsyg.2017.02048

Bollen, K.A. \& Long, J.S. (1993). Testing structural equation models. Beverly Hills: Sage.

Bradshaw, C. P., Waasdorp, T. E., \& Leaf, P. J. (2012). Effects of school-wide positive behavioral interventions and supports on child behavior problems. Pediatrics, 130(5), e1136-e1145. doi:10.1542/peds.2012-0243

Bronfenbrenner, U. (1986). Ecology of the family as a context for human develpment: Research perspectives. Developmental Psychology, 22, 723. doi:10.1037/0012-1649.22.6.723

Brophy, J. (2010). Motivating students to learn (3rd ed. ed.). New York: Routledge.

Browne, M. W. \& Cudeck, R. (1993). Alternative ways of assessing model fit. Sage focus editions, 154, 136-136.

Byrne, B. M. (2001). Structural equation modeling with amos. Basic concepts, applications and programming. Mahwah, NJ: Lawrence Eribaum Associates.

Carvalho, S., Pinto, G. P., Pimentel, P., Maia, D., \& Mota-Pereira, J. (2011). Características psicométricas da versão portuguesa da Escala Multidimensional de Suporte Percebido (Multidemensioal Scale of Perceived Social Support - MSPSS). Psychologica, 54, 309-358. 
Cheon, S., Reeve, J., Yu, T., \& Jang, H. (2014). The Teacher Benefits From Giving Autonomy Support During Physical Education Instruction. Kangwon National University; Korea University. Journal of Sport y Exercise Psychology, 36, 331-346. doi:10.1123/jsep.2013-0231

Chiu, M. M. \& Chow, B. W. (2011). Classroom discipline across 41 countries: school, economic, and cultural differences. Journal of Cross-Cultural Psychology, 42, 516-533. doi: $10.1177 / 0022022110381115$

Chu, P. S., Saucier, D. A., \& Hafner, E. (2010). Meta-analysis of the relationship between social support and well-being in children and adolescents. Journal of Social and Clinical Psychology, 29(6), 624-645. doi:10.1521/jscp.2010.29.6.624

Cook, D. A. \& Artino Jr, A. R. (2016). Motivation to learn: an overview of contemporary theories. Medical Education, 50, 997-1014. doi:10.1111/medu.13074

Cuevas, R., García-Calvo, T., \& Contreras, O. (2013). Perfiles motivacionales en Educación Física: una aproximación desde la teoría de las Metas de Logro 2x2. Anales de Psicología, 29(3), 685-692.

Davis, H. A. (2003). Conceptualizing the role and influence of student-teacher relationship on children's social and cognitive development. Educational Psychologist, 38(4), 207-234. doi:10.1207/S15326985EP3804_2

De Vincenzi, A. (2009). Teaching Concepts and Their Relationship to Teaching Practices: A Study with University Professors. Universidad de La Sabana, 12(2), 87-101.

Deci, E. L., \& Ryan, R. M. (1985). Intrinsic motivation and Self-determination in human

behavior. New York: Plenum.Deci, E. L. \& Ryan, R. M. (Eds.). (2002). Handbook of selfdetermination research. University Rochester Press.

Drugli, M. B. (2013). How are closeness and conflict in student-teacher relationship associated with demographic factors, school functioning and mental health in Norwegian schoolchildren aged 6-13? Scandinavian Journal of Educational Research, 57, 217-225. doi:10.1080/003 13831.2012 .656276

Dubow, E. F. \& Ullman, D. G. (1989). Assessing social support in elementary school children: The survey of children's social support. Journal of Clinical Child Psychology, 18(1), 52-64. doi:10.1207/s15374424jccp1801_7

Durlak, J. A., Weissbert, R. P., Dymnicki, A. B., Taylor, R. D., \& Schellinger, K. B. (2011). The impact of enhancing students' social and emotional learning: A meta-analysis of schoolbased universal interventions. Child Development, 82(1), 405-432. doi:10.1111/j.14678624.2010.01564.x

Elmose, M. \& Lasgaard, M. (2017). Loneliness and social support in adolescent boys with Attention Deficit Hyperactivity Disorder in a special education setting. Journal of Child and Family Studies, 26, 2900-2907. doi:10.1007/s10826-017-0797-2

Engelschalk, T., Steuer, G., \& Dresel, M. (2016). Effectiveness of motivational regulation: Dependence on specific motivational problems. Learning and Individual Differences, 52, 72-78. doi:10.1016/j.lindif.2016.10.011

Finney, S. J. \& DiStefano, C. (2006). Non-normal and categorical data in structural equation modeling. Structural equation modeling: A second course, 10(6), 269-314.

Fredriksen, K. \& Rhodes, J. (2004). The role of teacher relationship in the lives of students. New Directions for Youth Development(103), 45-54. doi:10.1002/yd.90 
Gagné, M. (2003). The role of autonomy support and autonomy orientation in prosocial behavior engagement. Motivation and Emotion, 27, 199-223. doi:10.1023/A:1025007614869

García, F. J. \& Doménech, F. (2002). Revista Electrónica de Motivación y Emoción. Universidad Jaume I de Castellón, 1(6).

Gargallo, B., Sánchez, F., Ros, C., \& Ferreras, A. (2010). Estilos docentes de los profesores universitarios. La percepción de los alumnos de los buenos profesores. Revista Iberoamericana de Educación, 51(4).

González-Cutre, D., Sierra, A. C., Montero-Carretero, C., Cervelló, E., Esteve-Salar, J., \& Alonso-Álvarez, J. (2015). Evaluación de las propiedades psicométricas de la Escala de Satisfacción de las Necesidades Psicológicas Básicas en General con adultos españoles. Terapia Psicológica, 33(2), 81-92.

Hagger, M. S., Chatzisarantis, N. L., Hein, V., Pihu, M., Soos, I., \& Karsai, I. (2007). The perceived autonomy support scale for exercise setting (PASSES): Development, validity, and cross-cultural invariance in young people. Psychology of Sport and Exercise, 8, 632653. doi:10.1016/j.psychsport.2006.09.001

Hambleton, R. K. \& Patsula, L. (1998). Adapting tests for use in multiple languages and cultures. Social indicators research, 45(1-3), 153-171 doi:10.1023/A:1006941729637

Härdle, W., \& Simar, L. (2003). Applied Multivariate Statistical Analysis. Berlin, Germany: Springer Verlag.

Harter, S. (1985). Manual for the social support scale for children. Denver, CO: Unversity of Denver.

Hu, L. T. \& Bentler, P. M. (1999). Cutoff criteria for fit indexes in covariance structure analysis: Conventional criteria versus new alternatives. Structural Equation Modeling: $a$ Multidisciplinary Journal, 6(1), 1-55. doi:10.1080/10705519909540118

Jenkins-Guarnieri, M. A., Vaughan, A. L., \& Wright, S. L. (2015). Development of a selfdetermination measure for college students: Validity evidence for the Basic Needs Satisfaction at college scale. Measurment and Evalutaion in Counseling and Development, 48(4), 266-284. doi:10.1177/0748175615578737

Koch, F. D., Dirsch-Weigand, A., Awolin, M., Pinkelman, R. J., \& Hampe, M. J. (2017). Motivating first-year university students by interdisciplinary study projects. European Journal of Engineering Education, 42(1), 17-31. doi:10.1080/03043797.2016.1193126

Kriegbaum, K., Jansen, M., \& Spinath, B. (2015). Motivation: A predictor of PISA's mathematical competence beyond intelligence and prior test achievement. Learning and Individual Differences, 43, 140-148. doi:10.1016/j.lindif.2015.08.026

Lam, S., Wong, B.H., Yang, H., \& Liu, Y. (2012). Understanding student engagement with a contextual model. En S. L. Christenson, A. L. Reschly y C. Wylie (Eds.), Handbook of research on student engagement (pp. 403-419). New York, NY US: Springer Science. doi:10.1007/978-1-4614-2018-7_19

Lei, H., Cui, Y., \& Chiu, M. M. (2018). The relationship between teacher support and student's academic emotions: A meta-analysis. Frontiers in Psychology, 8, 2288. doi.org/10.3389/ fpsyg.2017.02288 
León, J., Núñez, J., Ruiz-Alfonso, Z., \& Bordón, B. (2015). Rendimiento académico en Música: efecto de la motivación intrínseca y el pensamiento crítico. Revista de Psicodidáctica, 20(2), 377-391. doi:10.1387/RevPsicodidact.12673

Liu, W. C., Wang, C. K., Tan, O. S., Koh, C., \& Ee, J. (2009). A self-determination approach to understanding students' motivation in project work. Learning and Individual Differences, 19, 139-145. doi:10.1016/j.lindif.2008.07.002

Loera, B., Martini, M., Viotti, S., \& Converso, D. (2016). Users' support as a social resource in educational service: Construct validity and measurment invariance of the User-Initiated Support Scale (UISS). Frontiers in Psychology, 7, 1248. doi:10.3389/fpsyg.2016.01248

Longobardi, C., Prino, L. E., Marengo, D., \& Settanni, M. (2016). Student-teacher relationship as a protective factor for school adjustment during the transition from middle to high school. Frontiers in Psychology, 7, 1988. doi:10.3389/fpsyg.2016.01988

Lynn, M. R. (1986). Determination and quantification of content validity. Nursing research. doi:10.1097/00006199-198611000-00017

Malecki, C. K., Demaray, M. K., \& Elliott, S. N. (2000). The child and adolescent social support scale. DeKalb, IL: Northern Illinois University.

McDonald, R. P. \& Marsh, H. W. (1990). Choosing a multivariate model: Noncentrality and goodness of fit. Psychological Bulletin, 107(2), 247. doi:10.1037/0033-2909.107.2.247

Moran, C. M., Diefendorff, J. M., Kim, T., \& Liu, Z. (2012). A profile apprach to self-determination theory motivations al work. Journal of Vocational Behavior, 81, 354-363. doi.org/10.1016/j. jvb.2012.09.002

Moreno, J. A., Parra, N., \& González-Cutre, D. (2008). Influencia del apoyo a la autonomía, las metas sociales y la relación con los demás sobre la desmotivación en educación física. Psicothema, 20(4), 636-641.

Morris, M. D., Neilands, T. B., Andrew, E., Maher, L., Page, K. A., \& Hann, J. A. (2017). Development and validation of a novel scale for measuring interpersonal factors underlying injection drug using behaviours among injecting partnerships. International Journal of Drug Policy, 48, 54-62. doi:10.1016/j.drugpo.2017.05.030

Niemic, C. P. \& Ryan, R. (2009). Autonomi, kompetence og indbyrdes relationer i klasseværelset. I Kognition og Padagogik, (74).

Norusis, M. J. (1992). SPSS-PC Plus Base System User's Guide, Version 5.0. SPSS Incorporated. Núñez, J. L., Martín-Albo, J., \& Navarro, J. (2005). Validación de la versión española de la Échelle de Motivation en Éducation. Psicothema, 17(2), 344-349.

Orsini, C., Binnie, V. I. y Wilson, S. L. (2016). Determinants and outcomes of motivation in health professions education: a systematic review based on self-determination theory. Journal of Educational Evaluation for Health Professions, 13(19). doi:10.3352/jeehp.2016.13.19

Paixão, O.\& Gamboa, V. (2017). Motivational profiles and career decision making of high school students. The Career Development Quarterly, 65, 207-221. doi:10.1002/cdq.12093

Pelletier, L. G., Beaudry, S., Sharp, E., \& Otis, N. (2008). The Interpersonal Behaviors Scale: A measure of autonomy support, competence and relatedness in different life domains. Educational and Psychological Measurement. 
Perdue, N. H., Manzeske, D. P., \& Estell, D. B. (2009). Predicting school commitment at grade five: Exploring the role of students' relationships with peer and teachers from grade three. Psychology in the Schools, 46, 1084-1097. doi:10.1002/pits.20446

Pintrich, P. \& De Groot, A. (1990). Motivational and self-regulated learning components of classroom academic performance. Journal of Educational Psychology, 82, 33-40. doi:10.1037/0022-0663.82.1.33

Pössel, P., Burton, S. M., Cauley, B., Sawyer, M. G., Spence, S. H., \& Sheffield, J. (2018). Associations between social support from family, friends, and teachers and depressive symptoms in adolescents. Journal of Youth and Adolescence, 47, 398-412. doi:10.1007/ s10964-017-0712-6

Pössel, P., Rudasill, K. M., Sawyer, M. G., Spence, S. H., \& Bjerg, A. C. (2013). Associations between teacher emotional support and depressive symptoms in Australia adolescents: A 5-year longitudinal study. Developmental Psychology, 49, 2135-2146. doi:10.1037/ a0031767

Quin, D., Hemphill, S. A., \& Heerde, J. A. (2017). Associations between teaching quality and secondary student's behavioral, emotional, and cognitive engagement in school. Social Psychology of Education, 20, 807-829. doi:10.1007/s11218-017-9401-2

Ratelle, C. F., Guay, F., Vallerand, R. J., Larose, S., \& Senécal, C. (2007). Autonomous, controlled, and amotivated types of academic motivation: A person-oriented analysis. Journal of Educational Psychology, 99, 734-746. doi:10.1037/0022-0663.99.4.734

Reeve, K. L., Shumaker, C. J., Yearwood, E. L., Crowell, N. A., \& Riley, J. B. (2013). Perceived stress and social support in undergraduate nursing students' educational experiences. Nurse Education Today, 33, 419-424. doi:10.1016/j.nedt.2012.11.009

Riley, G. (2016). The role of self-determination theory and cognitive evaluation theory in home education. Cogent Education, 3. doi:10.1080/2331186X.2016.1163651

Rodríguez, M. N., \& Ruiz, M. Á. (2008). Atenuación de la asimetría y de la curtosis de las puntuaciones observadas mediante transformaciones de variables: Incidencia sobre la estructura factorial. Psicológica, 29, 205-227. doi:10.3389/fpsyg.2017.00076

Ryan, R. M. (1991). The nature of the self in autonomy and relatedness. En J. Strauss y G. R. Goethals (Eds.), The self: Interdisciplinary appraches (pp. 208-238). New York: SpringerVerlag.

Ryan, R.M. \& Deci, E. L. (2000). Self-Determination Theory and the Facilitation of Intrinsic Motivation, Social Development, and Well-Being. American Psychologist, 55(1) 68-78. doi:10.1007/978-1-4684-8264-5_11

Ryan, R. M., \& Deci, E. L. (2000a). Intrinsic and extrinsic motivations: Classic definitions and new directions. Contemporary Educational Psychology, 25(1), 54-67. doi:10.1006/ ceps.1999.1020

Ryan, R. M., \& Deci, E. L. (2013). Toward a social psychology of assimilation: Self-determination theory in cognitive development and education. In B. W. Sokol, F. M. E. Grouzet, \& U. Müller (Eds.), Self-regulation and autonomy: Social and developmental dimensions of human conduct (pp. 191-207). Cambridge, UK: Cambridge University Press. https://doi. org/10.1017/CBO9781139152198.014 
Ryan, R. M., \& Deci, E. L. (2019). Brick by brick: The origins, development, and future of selfdetermination theory. In A. J. Elliot (Ed.), Advances in Motivation Science (pp. 111-162). Elsevier. https://doi.org/10.1016/bs.adms.2019.01.001

Rzeszutek, M. (2017). Social support and posttraumatic growth in a longitudinal study of people living with HIV: the mediating role of positive affect. European Journal of Psychotraumatology, 8, 1. doi:10.1080/20008198.2017.1412225

Sadler, P., Ethier, N., Gunn, G. R., Duong, D., \& Woody, E. (2009). Are we on the same wavelength? Interpersonal complementarity as shared cyclical patterns during interactions. Journal of Personality and Social Psychology, 97, 1005-1020. doi:10.1037/a0016232

Schunk, D. H., Pintrich, P. R., \& Meece, J. (2008). Motivation in education: Theory, research and applications (3rd ed. ed.). NJ: Pearson/Merrill Prentice Hall: Upper Saddle River.

Sheldon, K. M. \& Hilpert, J. C. (2012). The Balanced Measure of Psychological Needs (BMPN) scale: An alternative domain general measure of need satisfaction. Motivation and Emotion, 36, 439-451. doi:10.1007/s11031-012-9279-4

Sherbourne, C. D. \& Stewart, A. L. (1991). The MOS social support survey. Social Science y Medicine, 32(6), 705-714. doi:10.1016/0277-9536(91)90150-B

Silveira, R. T. (2018). A relação professor-aluno de uma perspectiva Gramsciana. Educação y Realidade, 43(1), 97-114. doi:10.1590/2175-623664512

Silverman, M. J. (2014). Effects of a live educational music therapy intervention on acute psychiartric impatients' perceived social support and trust in the therapist: A four-group randomized effectiveness study. Journal of Music Therapy, 51(3), 228-249. doi:10.1093/ jmt/thu011

Siqueira, M. M. (2008). Construção e validação da Escala de Perceção de Suporte Social. Psicologia em Estudo, 13(2), 381-388. doi:10.1590/S1413-73722008000200021

Sulkowski, M. L. \& Simmons, J. (2018). The protective role of teacher-student relationship against peer victimization and psychosocial distress. Psychology in the Schools, 55, 137150. doi:10.1002/pits.22086

Vallerand, R. J., Blais, M. R., Brière, N. M., \& Pelletier, L. G. (1989). Construction et validation de l'échelle de motivation en éducation (EME). Canadian Journal of Behavioural Science/ Revue canadienne des sciences du comportement, 21(3), 323. doi:10.1037/h0079855

Vallerand, R. J. \& Lalande, D. R. (2011) The MPIC Model: The Perspective of the Hierarchical Model of Intrinsic and Extrinsic Motivation. Psychological Inquiry, 22(1), 45-51. doi:10.1 080/1047840X.2011.545366

Vansteenkiste, M., Sierens, E., Soenens, B., Luyckx, K., \& Lens, W. (2009). Motivational profiles from self-determination perspective: The quality of motivation matters. Journal of Educatinal Psychology, 101, 671-688. doi:10.1037/a0015083

Vansteenkiste, M., Niemiec, C. and Soenens, B. (2010), The development of the five minitheories of self-determination theory: an historical overview, emerging trends, and future directions, Urdan, T. and Karabenick, S. (Ed.) The Decade Ahead: Theoretical Perspectives on Motivation and Achievement (Advances in Motivation and Achievement, Vol. 16 Part A), Emerald Group Publishing Limited, Bingley, pp. 105-165. https://doi.org/10.1108/S07497423(2010)000016A007 
Vaz, T. R. (2010). Vivências académicas e suporte social na adatptação ao ensino superior dos estudantes do $1^{\circ}$ ano da Universidade da Beira Interior (tesis de maestría). Universidade da Beira Interior.

Vincent, J.W. (1995). Statistics in kinesiology. Champaign, IL: Human Kinetics.

Vlachopoulos, S. P. y Michailidou, S. (2006). Development and initial validation of a measure of autonomy, competence, and relatedness: the Basic Psychological Needs in Exercise Scale. Measurement in Physical Education and Exercise Science, 10, 179-201. doi:10.1207/ s15327841mpee1003_4

Zaikin, O., Tadeusiewicz, R., Rózevski, P., Busk Kofoed, L., Malinowska, M., \& Zylawski, A. (2016). Teachers' and students' motivation model as a strategy for open distance learning processes. Bulletin of the Polish Academy of Sciences, 64(4), 943-955. doi:10.1515/ bpasts-2016-0103

Zhuang, Y., Feng, W. y Liao, Y. (2017). Want more? Learn less: Motivation affects adolescents learning form negative feedback. Frontiers in Psychology, 8(76). doi:10.3389/ fpsyg.2017.00076 